\title{
Assessment of the debt burden and the crediting risks of the population of Russia and the Volgograd region
}

\author{
Alla V. Litvinova \\ Volzhskiy Branch, \\ Volgograd State University, \\ Chair of Finance and Credit \\ Volzhskiy, Russia \\ litvinova_av@mail.ru \\ Elena G. Chernaya \\ Volzhskiy Branch, \\ Volgograd State University, \\ Chair of Finance and Credit \\ Volzhskiy, Russia \\ tchornaja@mail.ru
}

\author{
Evgeniy O. Litvinov \\ Volzhskiy Branch, \\ Volgograd State University, \\ Chair of Finance and Credit \\ Volzhskiy, Russia \\ eo_litvinov@mail.ru
}

\author{
Dmitriy A. Ovcharov \\ Volgograd State University, \\ Institute of Economics and Finance, \\ Chair of Economic Theory, \\ World and Regional Economics \\ Volgograd, Russia \\ ovcharovda@volsu.ru
}

\begin{abstract}
In the article the role of the assessment of the debt burden of the population as a tool of the risk reduction in the retail crediting is specified. This evaluation will help limit the access to credit resources to the borrowers with a high probability of the non repayment of borrowed money. The situation with the past due debts in the retail crediting sector in Russia is analyzed. The review of the use of the universally recognized ratios of the debt burden DTI and PTI in the international and domestic banking practice is presented. The way of the calculation of the debt burden of the population at the national and at the regional levels is suggested. This methodology shows the relation of current credit obligations and the incomes of the population employed in the economy who are the main borrowers of credit resources. A comparative analysis of the scale and the dynamics of the debt burden for credits of individuals in Russia and in the Volgograd region is carried out. The measures for the reduction of the debt burden of the population on the country and its regions are suggested.
\end{abstract}

Keywords - credit, crediting of the population, debt burden, DTI ratio, PTI ratio, credit risks

\section{INTRODUCTION}

The international experience of the assessment of risks of retail crediting shows that the use of the ratios capable of objectively and reliably evaluating the debt burden of the borrowers (individuals) becomes more and more important and demanded by all the participants of credit relations.

The assessment of the debt burden gives the opportunity to the borrower to make the reasonable choice of credit programs on the basis of the assessment of their real opportunities to pay fully its debts as they fall due. The regulator gets the opportunity of forecasting the potential size of the past due indebtedness, of preventing its appearance and by means of that reducing the risks of retail crediting. The assessment of the debt burden of borrowers increases the safety of the activity of commercial banks and allows improving the control measures of the creditworthiness of borrowers and also it serves as a reliable tool of the competition development between banks as focuses them on the improvement of their credit programs first of all in part of the optimization of the interest rates on credits.

The indices of the debt burden although they express different interests of the participants of credit relations in the end assess the most important for all the actors the risk of the appearance of past due debts for credits which sharply reduces the efficiency of functioning of the whole credit and banking system of the country. The calculation of the indices of the debt burden solves the problem of the reduction of risks of retail crediting by means of the limitation of the access to the credit resources of the borrowers with a high probability of the non repayment of borrowed money.

The goal of the research is the assessment of the debt burden of the population in Russia and in the Volgograd region on the basis of the indices accepted in the world practice and the development of measures directed on the reduction of crediting risks of the population of Russia and its regions. 


\section{MATERIALS AND METHODS}

In the crediting practice of developed countries a wide use have two ratios of the debt burden of the population: DTI and PTI. Their synonyms are DSTI and DSR indices.

The DTI (debt to income) ratio is calculated as the ratio of the total indebtedness of the borrower in credits to its income per 12 months as a rule. The PTI (payment to income) ratio is determined as the ratio of the amount of the monthly payment of the borrower of all credits (principals and interest) and the average monthly income taken as a rule for 12 months.

In February 2017 the Bank of Russia published and presented for discussion of the banking community of the country the report «About the assessment of the borrowers (individuals) risks using the debt burden ratios» [1]. It contained the analysis of the advantages and drawbacks of the DTI and PTI ratios and also the methodical guidelines for their calculation suggested by the regulator.

The common drawback for both DTI and PTI ratios is, first of all, the dependence of their values on the term of the crediting of an individual, i.e. at other equal conditions (equal sum of the credit and interest rates) the values of the debt burden for different terms of credit vary considerably. And together with the prolongation of the term of the credit agreement the values of these indices decrease. In the result the deliberate distortion of their value due to the prolongation of the term of the credit can happen. Secondly, for both of the ratio there are no common normative values in the world practice. The norms are needed that would determine an acceptable risk of crediting determined by the possibility of the appearance of the indebtedness of a borrower.

Both of the ratios can be calculated at the moment of the study of the application for a credit and also during the term of the agreement. But at the same time the PTI ratio is more informative for the assessment of the credit risks of a specific borrower and it is easier to interpret it. The advantage of the DTI index is the simplicity of its calculation and the low operation costs of bank creditor connected with that.

Besides the report of the Bank of Russia the review of the international practice of the calculation of the debt burden ratios shows that in a number of countries (Hungary, Ireland, Lithuania, South Corea and others) the evaluation of the debt burden (PTI mainly) is not obligatory. The object of the debt burden of the population are in general the mortgage loans. In every country its own limitation values of the debt burden ratios are set. The minimal values of these ratios vary in considerably wide band of values (from 10 to $80 \%$ ) in dependence of the type of credit, income of the borrower, currency of the credit. Judging from the review of the Bank of Russia the conclusion can be made that the acceptable secure level of the debt burden ratio in the international practice of crediting makes up $40 \%$. Together with that the control of the dynamics of the indices in respect of every specific borrower is carried out.

In Russia the calculation of the indices of the debt burden still has a non obligatory character. The normative limitation in the values of the indices of the debt burden is not set by the Bank of Russia. The exception are the mortgage loans when the DTI or PTI ratio are not calculated. But in compliance with the Guidelines of the Bank of Russia adopted December, 32012 № 139-I «About the required normative values of the banks» the ratios of the total year income of the borrower (other members of the family) to the total year sum of the payments (principal and interest) or Income/Payment is calculated and the risk coefficient is assessed. Since January, 1 2016 in compliance with the Guidelines of the Bank of Russia dated 30.11.2015 № 3855-U the minimal coefficient of risk at $35 \%$ is set for mortgage loans with the ratio Income/Payment more than 3,0 .

In the opinion of E.V. Kazakova [2] the use of the indices of the debt burden is the reaction of the banking system to the excess of real disposable incomes of the population over their real incomes. In his turn A. Volkov fairly states that these indices are the efficient tools of banking risk management and they give the opportunity of clearly comparing the creditworthiness of the borrower and the obligations that he plans to undertake. The doubtless use from the calculation of the debt burden indices allowing not only specifying real and potential risks of retail crediting but also to influence their value is faced however with the differences in the definition of the content and of the assessment of the optimal values of these indices. Despite that in the world practice a considerable experience of use of the debt burden indices of the population has been accumulated. The existing drawbacks of their calculation and the use limit the possibilities of the creditors in the reduction of the risks of the retail crediting.

Taking into account that the debt burden of the borrowers influences the stability of the credit and banking system of the state in the whole, the calculation of not only the individual debt burden is of interest but also it also the debt burden of the population at macro and meso levels of the credit and banking system. It is suggested to modify the calculation of the ratio of the DTI debt burden through the assessment of the relation between factual credit obligations of the borrowers (individuals) and the incomes of the population employed in the economy who are the main target audience in the sphere of retail banking crediting in Russia:

$$
\mathrm{DTI}=\mathrm{C} / \mathrm{I}_{\text {av per capita }} \times 12 \times \mathrm{N}_{\text {num empl }},
$$

where DTI - ratio of credits given to the population to the income of the population, $\%$

$\mathrm{C}$ - credits given to the population, million rubles;

I av per capita - average income per capita every month, rubles;

12 - number of months in a year (when calculating the DTI ratio per year);

$\mathrm{N}$ num empl - number of the employed in the economy, thousand people.

The proposed index of the debt burden of the population is capable of being a macroeconomic indicator of the risks of retail crediting determined by the possibility of the non fulfillment by the borrowers (individuals) of their credit obligations. It is also determined by the efficiency of the bank control of their creditworthiness in the whole country and its regions. The quantitative measure of this index and its analysis in dynamics allow changing intentionally the parameters of the development of credit and banking system of the state for 
the growth of its financial stability and the growth of the efficiency of the macroprudential measures in the reduction of credit risks in the sphere of retail crediting.

\section{RESULTS AND DISCUSSION}

The analysis of the twenty years (from 1998 to 2017) of functioning of the banking system of Russia showed high risks in the sphere of the retail crediting determined by the extremely unfavourable situation with past due debts of the borrowers (individuals). The official banking statistics evidences about the fact that for the mentioned period the absolute value of the past due indebtedness constantly grew (by 01.09.2017 2267 times in comparison with the data by 01.01.1998, and in particular it grew from 423 million rubles to 958946 million rubles). This index showed the reduction only one time by 01.01 .2017 (by 106739 million rubles in comparison with 2015). The absolute volume of the past due debts reached its maximal value (1084298 million rubles) according to the results of 2015 . In the same year the share of past due debts in the total volume of the credits made up a historically high value $(10,5 \%)$. It is worth mentioning that the tendency of the change of the share of past due debts in credits from 1998 to 2017 was not evident. This index both increased and then decreased. It reached the historical minimum of $1,2 \%$ by 01.01 .2004 but in total it showed a positive trend. In 20162017 the positive tendency of the reduction of the share of the past due debts from credits in the total volume of the credits started to appear. According to the results of the year 2016 this index reduced by $9,3 \%$, and by 01.09 .2017 it dropped to $8,5 \%$ $[4,5]$.

The growth of the volumes of the past due indebtedness in the conditions of the growth of crediting is a regular manifestation. During some periods of time (2001, 2003-2005) the volumes of the credits granted to the population grew more than twofold. In 2007 and 2008 the volumes were close to the duplication in comparison with the previous year. Only in 2009 and 2015 the dynamics of the volumes of the granted credits was negative (growth rate of the credit volumes made up 0,89 and 0,94 correspondingly). In the whole the situation is such that for twenty years or by September 2017 the volumes of the granted credits grew 649 times in comparison with 1997 (11230,071 billion rubles by 01.09.2017 and 17,3 billion rubles by 01.01 .1998$)[4,5]$.

But in this case it is not the growth of the volumes of the credits are important but the relation of their dynamics with the dynamics of the DTI ratio. The efficiency of the retail crediting from the point of view of the value and the dynamics of the debt burden of the population is provided at the observance of the following condition: growth of the volumes of the granted credits should be accompanied by the reduction (constant values) of the DTI ratio.

The DTI index calculated on the basis of the population employed in the economy and on the basis of their average incomes per year (calculation of the DTI ratio according to the data $[4,5,6]$ is presented in Table 1) for the analyzed period showed in the whole a negative dynamics. Starting from 2001 according to the results of the year the DTI ratio stably grew having reduced only twice (in 2009 and 2015) and after every reduction it restarted the growth.

The maximal value of the DTI ratio for the analyzed period made up $47,53 \%$ in the end of year 2014. Despite the fact that in 2015 this index decreased and then started to increase the rate of its growth in 2016-2017 slowed down and it is a positive tendency. In the whole however it can be said that the condition for the growth of the volumes of the granted credits which would be accompanied by the reduction (constant values) of the DTI ratio was never observed in the history of national retail crediting. For the period from 1997 to 2017 the volumes of the credits granted to the population grew 649 times and the DTI ratio at the same time grew 17,2 times (to $40,91 \%$ ) threatening the stability of the banking system.

TABLE 1. DYNAMICS OF DTI RATIO FOR CREDITS TO INDIDVIDUALS FROM 1997 TO 2017 IN RUSSIA

\begin{tabular}{|c|c|c|c|c|}
\hline $\begin{array}{c}\text { Period of } \\
\text { time }\end{array}$ & $\begin{array}{c}\text { Volumes of credits } \\
\text { total, million } \\
\text { rubles }\end{array}$ & $\begin{array}{c}\text { Monthly average } \\
\text { income per } \\
\text { capita rubles }\end{array}$ & $\begin{array}{c}\text { Number of } \\
\text { the employed } \\
\text { in the } \\
\text { economy, } \\
\text { thousand } \\
\text { people }\end{array}$ & \\
\hline 01.01 .1998 & 17316 & 1010 & 60021 & 2,38 \\
\hline 01.01 .1999 & 20022 & 1659 & 58437 & 1,72 \\
\hline 01.01 .2000 & 27630 & 2281 & 63082 & 1,60 \\
\hline 01.01 .2001 & 44748 & 3062 & 65070 & 1,87 \\
\hline 01.01 .2002 & 94635 & 3947 & 65123 & 3,07 \\
\hline 01.01 .2003 & 142158 & 5170 & 66659 & 3,43 \\
\hline 01.01 .2004 & 299678 & 6410 & 66339 & 5,87 \\
\hline 01.01 .2005 & 618862 & 8112 & 67319 & 9,44 \\
\hline 01.01 .2006 & 1179250 & 10196 & 68339 & 14,10 \\
\hline 01.01 .2007 & 2065199 & 12603 & 69169 & 19,74 \\
\hline 01.01 .2008 & 3242111 & 14943 & 70770 & 25,55 \\
\hline 01.01 .2009 & 3687527 & 14864 & 71003 & 31,72 \\
\hline 01.01 .2010 & 3297071 & 16895 & 69410 & 25,39 \\
\hline 01.01 .2011 & 3732162 & 18958 & 69934 & 25,67 \\
\hline 01.01 .2012 & 5115069 & 20780 & 70857 & 31,42 \\
\hline 01.01 .2013 & 7349035 & 23221 & 71545 & 38,81 \\
\hline 01.01 .2014 & 9536025 & 25928 & 71391 & 44,83 \\
\hline 01.01 .2015 & 10909524 & 27767 & 71539 & 47,53 \\
\hline 01.01 .2016 & 10278829 & 30467 & 72324 & 38,87 \\
\hline 01.01 .2017 & 10494118 & 30738 & 72393 & 39,93 \\
\hline 01.09 .2017 & 11230071 & 31422 & 72800 & 40,91 \\
\hline
\end{tabular}

In the fair opinion of M. Skuditis and A. Bikbov [7] a high value of the DTI ratio is generally the consequence of the high price of the credits in Russia which is determined by the interest rates.

The analysis of the banking statistics shows that the minimal value of the weighted average interest rate for retail credits for twenty years taken for the analysis was recorded on 
01.01.2007 (19,5\%). The year 2006 became the last year in the contemporary history of Russia after which the DTI ratio exceeded the psychologically important barrier of $20 \%$. The share of past due debts in 2006 was at an extremely low level of $2,6 \%$ [4,5]. It should be noted that the period from 2000 to 2007 was extremely successful from the point of view of the non performance of the obligations by the borrowers and from the point of view of the values of the DTI ratio. The share of the past due debts varied from 1,2 to $3,1 \%$ and the value of DTI varied from 1,60 to $19,74 \%$.

Despite the fact that for the mentioned period of time the problems typical both for the current stage of the economic development of the country (high dependence on the prices of the main export goods in the world market, poor diversification of the Russian economy, low efficiency of the state administration, technological backwardness etc.) took place. But at the same moment a favourable macroeconomic situation was observed.

The reduction of the unemployed rate and the growth of the number of the employed in the economy were observed. Thus at 2006 year end the number of the population employed in the economy grew by 857 thousand people in comparison with 2005 having reached the value of 69169 thousand people. Together with that beginning from 2009 the reduction of this ratio until the lowest value of this ratio for whole period of analysis (69410 thousand people) was observed. Further the growth of this ratio was inconsiderable. The stable growth of the average income per capita and real disposable incomes of the population of the country was observed. Thus by 2007 real disposable incomes of the population reached $113,5 \%$ in comparison with the previous year. On this basis the growth of the internal demand and consumer expenses of the population took place. Due to this circumstance the low value of the DTI ratio and the low value of the share of the past due indebtedness of the population for retail credits for the period from 2005 to 2007 is explained. Starting from 2014 a sharp reduction of real disposable incomes of the population was recorded. By the end of year 2016 their value reached a historically low value or precisely $94,1 \%$ in comparison with the previous year.

The dynamics of the debt burden for credits to individuals in the Volgograd region has its specificity but in the whole is a reflection of the situation in Russia (Table 2).

The analysis of the dynamics of the ratios characterizing the debt burden of the population for 2008 to 2017 showed the growth of the volumes of the granted credits until year the 2014 and then the following sharp reduction in 2015 (more than 1,5 times). In 2016 the increase of the granted credits recovered and by 01.01.2017 it reached 90096 million rubles what was higher than the level of 2016 almost 1,3 times. Average income per capita of the population of the region was growing until 2015 when it reached the value of 21718,8 rubles but by 01.01.2017 they reduced by 253,5 rubles. Besides as the official statistical data shows the real disposable income of the population beginning from 2012 started reducing. Their index dropped from $102,0 \%$ in 2012 to $90,7 \%$ at 2016 year end. The number of the employed in the economy started to demonstrate a negative dynamics even in 2014 and since then it was consistently reducing. By 01.01.2017 the number of the economically active population reduced by 56,2 thousand people in comparison with the data by 01.01 .2014 (on this date the maximal value of 1256,8 rubles of the index was recorded) $[8,9,10,11]$. The DTI ratio consistently grew having reached by $01.01 .201440,40 \%$ and then it reduced to $29,13 \%$ by 01.01 .2017 .

TABLE 2. DYNAMICS OF DTI RATIO FOR CREDITS TO INDIDVIDUALS FROM 1997 TO 2017 IN VOLGOGRAD REGION

\begin{tabular}{|c|c|c|c|c|}
\hline $\begin{array}{c}\text { Period of } \\
\text { time }\end{array}$ & $\begin{array}{c}\text { Volumes of credits } \\
\text { total, million } \\
\text { rubles }\end{array}$ & $\begin{array}{c}\text { Monthly average } \\
\text { income per } \\
\text { capita, rubles }\end{array}$ & $\begin{array}{c}\text { Number of } \\
\text { the employed } \\
\text { in the } \\
\text { economy, } \\
\text { thousand } \\
\text { people }\end{array}$ & $\begin{array}{c}\text { DTI, } \\
\%\end{array}$ \\
\hline 01.01 .2008 & 36677 & 9409,8 & 1278,7 & 25,40 \\
\hline 01.01 .2009 & 40345 & 10833,5 & 1213,5 & 25,59 \\
\hline 01.01 .2010 & 37012 & 12530,7 & 1202,9 & 20,46 \\
\hline 01.01 .2011 & 42564 & 13774,8 & 1219,3 & 21,12 \\
\hline 01.01 .2012 & 58313 & 14519,4 & 1243,0 & 26,92 \\
\hline 01.01 .2013 & 83129 & 16010,6 & 1251,9 & 34,56 \\
\hline 01.01 .2014 & 107172 & 17589,6 & 1256,8 & 40,40 \\
\hline 01.01 .2015 & 108774 & 19055,7 & 1229,7 & 38,68 \\
\hline 01.01 .2016 & 70367 & 21718,8 & 1213,3 & 22,25 \\
\hline 01.01 .2017 & 90096 & 21465,3 & 1200,6 & 29,13 \\
\hline
\end{tabular}

The comparison of the DTI ratio for credits to individuals for the period from 2008 to 2017 in Russia and in the Volgograd region (Table 3) shows that the tendency of the change of the debt burden of the population in the country and in the region are in general similar.

TABLE 3. COMPARATIVE CHARACTERISTIC OF THE DTI RATIO FOR CREDITS TO INDIDVIDUALS FROM 2008 TO 2017 IN RUSSIA AND IN THE VOLGOGRAD REGION

\begin{tabular}{|c|c|c|}
\hline \multirow{2}{*}{ Period of time } & \multicolumn{2}{|c|}{ DTI value } \\
\cline { 2 - 3 } & Russia & Volgograd region \\
\hline 01.01 .2008 & 25,55 & 25,40 \\
\hline 01.01 .2009 & 31,72 & 25,59 \\
\hline 01.01 .2010 & 25,39 & 20,46 \\
\hline 01.01 .2011 & 25,67 & 21,12 \\
\hline 01.01 .2012 & 31,42 & 26,92 \\
\hline 01.01 .2013 & 38,81 & 34,56 \\
\hline 01.01 .2014 & 44,83 & 40,40 \\
\hline 01.01 .2015 & 47,53 & 38,68 \\
\hline 01.01 .2016 & 38,87 & 22,25 \\
\hline 01.01 .2017 & 39,93 & 29,13 \\
\hline
\end{tabular}

Having started to grow practically from the same base after the ending of year 2007 (25,55\% in Russia and 25,40\% in the Volgograd region), the DTI ratio in the region reached its maximum $(40,0 \%)$ by 01.01 .2014 . In the whole in Russia the maximal value of DTI was recorded one year later and more precisely on $01.01 .2015(47,53 \%)$. However when amounting 
to their maximal value in the Volgograd region the values of the DTI ratio were 4-5\% lower than average Russian values of the debt burden. Having reached the maximum, the value of the DTI ratio started decreasing both in the whole Russia and in the Volgograd region. Meanwhile in the Volgograd region in 2015-2016 the situation with the debt burden of the population was more favourable. The value of the DTI ratio reduced from $38,68 \%$ by 01.01 .2015 to $22,25 \%$ by 01.01.2016. In Russia in the whole the decrease of the debt burden ratio was less evident. From the maximal level of $47,53 \%$ by 01.01 .2015 it dropped only to $38,87 \%$ by 01.01.2016. At 2016 year end DTI grew both in Russia (up to $39,93 \%$ ), and in the Volgograd region (to 29,13\%). However in the Volgograd region it remained at a tolerable level.

\section{CONCLUSION}

The comparative analysis of scale and dynamics of the debt burden of the credits of individuals in Russia and in the Volgograd region with the use of the DTI index reflecting the ratio of current credits and incomes of population of the employed in the economy showed that the tendencies of the change of the debt burden of the population of the country and of the regions in the country are similar. However in the Volgograd region the values of the index of the debt burden are lower than average ones in Russia. In connection with such unfavourable tendencies in social and economic situation of the Volgograd region as the reduction of disposable incomes of the population and of its economically active part, lower debt burden ratios and correspondingly a low level of the risks of retail crediting is exactly a positive aspect of the regional development at the modern stage of regional development as it does not allow appearing crisis "bubbles" in the financial system. This fact can be explained by a balanced and reasonable credit policy of commercial banks (including regional ones) working in the region and by the limitation of the access to credits of insolvent borrowers. The evidence of the toughening of the approaches to the assessment of the creditworthiness of borrowers is a sharp drop of the crediting of the population of the Volgograd region since 2015. Exactly in this period of time the debt burden of the population of the region reduced to an unprecedented level for previous years and exactly to $22 \%$. However a gradual growth of the debt burden at the reviving of the crediting of the population in the Volgograd region which is observed in 2016 requires a constant control of the processes taking place in the market of retail crediting from the Bank of Russia.

The necessity of the reduction of the debt burden of the population in the whole in Russia requires adequate prudential measures from the regulator. The limitation of the access to credits of borrowers with a high risk level under a tough control of the Bank of Russia is the main way of the reduction of the debt burden of the population. The most important for the assessment of the creditworthiness of borrowers are only their official incomes. In this respect some measures are taken. The draft legislation № 1072874-6 dated 16.05.2016 was presented to the State Duma of the Russian Federation (the Parliament) and it was reviewed in its first reading. In compliance with it the most reliable and least consciously distorted source of the information about potential borrowers (individuals) and about their incomes becomes the Pension
Fund of the Russian Federation. Besides the most important and unquestionable factor of the reduction of the debt burden of the population becomes the increase of its purchasing ability in case of the loans given by credit organizations and, consequently, of real disposable incomes of people. The problem of low incomes of the population is connected with the employment rate, creation of new jobs, increase of the labour productivity and other systemic issues. The continuance and complicatedness of this problem does not reduce but even more increases its relevance.

For the reduction of the risks of retail crediting it is indispensable to introduce into the banking practice the ratios which determine the obligation of use of the ratios of the debt burden of the population. The approval of the final version of the methods of calculation of the debt burden of the population for both individual borrowers and for the calculation of the debt burden at the level of the country and its regions is required. On the basis of the world practice of the assessment of the debt burden of the population, the Bank of Russia is expected to develop the optimal values of the limits for the debt burden of individuals. On the one hand they should not slow down artificially the lending processes and the growth of the human capital with the use of borrowed funds and on the other hand they should be capable of limiting the access to credits of the untrustworthy and insolvent borrowers.

\section{References}

[1] Doklad dlya obshchestvennykh konsul'tatsii «Ob otsenke riskov zaemshchikov - fizicheskikh lits na osnove pokazatelei dolgovoi nagruzki» [Report for public consulting "About the assessment of risks of borrowers (individuals) on the basis of the ratios of debt burden] Moscow: Central bank of the Russian Federation. February 2017. 24 p. Available at: http://www.cbr.ru/. Reference date: 15.02.2018

[2] Kazakova E.V. Potrebitel'skoe kreditovanie: sostoyanie, problemy i puti razvitiya [Consumer lending: condition, problems and ways of development]. Lex russica, 2016, № 7, pp. 6-12.

[3] Volkov A. Sposoby otsenki zaemshchikov [Ways of assessment of borrowers]. Bankovskoe obozrenie. Prilozhenie «BEST PRACTICE» [Bank survey. Annex «BEST PRACTICE»], 2015, № 1, pp. 19-27.

[4] Statisticheskii byulleten' Banka Rossii za 1997-2017 gg. [Statistical bulletin of the Bank of Russia for 1997-2017]. Available at: http://www.cbr.ru/publ/?PrtId=bbs. Reference date: 15.02 .2018

[5] Informatsiya o riskakh kreditovaniya fizicheskikh lits [Information about the risks of individuals' crediting]. Available at: http://www.cbr.ru/statistics/print.aspx?file=bank_system/risk. Reference date: 15.02 .2018

[6] Srednedushevye denezhnye dokhody naseleniya po Rossiiskoi Federatsii v 2008-2016 gg. [Average income per capita of the population of the Russian Federation in 2008-2016]. Available at: http://www.gks.ru/free_doc/new_site/population/urov/urov_11kv.htm. Reference date: 15.02 .2018

[7] Skuditis M., Bikbov A. Kreditnyi puzyr' [Credit bubble]. Prakticheskaya bukhgalteriya [Practical accounting], 2013, № 10, pp. 12-17.

[8] Osnovnye sotsial'no-ekonomicheskie indikatory urovnya zhizni naseleniya [The main social and economic indicators of the standard of life of the population]. Available at: http://volgastat.gks.ru/wps/wcm/connect/rosstat_ts/volgastat/ru/statistics /standards_of_life. Reference date: 15.02.2018

[9] Chislennost' rabochei sily, zanyatykh i bezrabotnykh [Number of labour force, employed and unemployed in the economy]. Available at: http://volgastat.gks.ru/wps/wcm/connect/rosstat_ts/volgastat/resources. Reference date: 15.02 .2018 
[10] Volgogradskaya oblast' v tsifrakh. 2015: kratkii sb. Terr. organ Fed. sluzhby gos. statistiki po Volgograd. obl. [Volgograd region in figures. 2015. Short digest. Territorial branch of the Federal Service for State Statistics]. Volgograd: Volgogradstat Publ., 2016, 376 p. Available at: http://volgastat.gks.ru/. Reference date: 15.02.2018
[11] Volgogradskaya oblast' v tsifrakh. 2016: kratkii sb. Terr. organ Fed. sluzhby gos. statistiki po Volgograd. obl. [Volgograd region in figures. 2016. Short digest. Territorial branch of the Federal Service for State Statistics]. Volgograd: Volgogradstat Publ., 2017,376 p. Available at: http://volgastat.gks.ru/. Reference date: 15.02.2018 